\title{
Implementation of Language Development for Children in Daycare
}

\author{
Halimatus Sakdiah', Delfi Eliza², \\ 1,2 Department of Early Childhood Education, Universitas Negeri Padang, Indonesia \\ ${ }^{1}$ halimatussakdiah1972@gmail.com, ${ }^{2}$ delfieliza@fip.unp.ac.id
}

\begin{tabular}{ccc}
\hline First received: & Revised: & Final Accepted: \\
January 27, 2021 & June 17, 2021 & June 29, 2021 \\
\hline
\end{tabular}

\section{Abstract}

Language development activities in daycare are essential because they can increase children's vocabulary. This study aims to determine how the process of implementing children's language development activities in daycare centres. This study uses the qualitative method. The data were collected by observing the language development of children aged 2-4 years at the Twin Course Daycare and interviewing six caregivers there. The study results showed that the implementation of language development in the Twin Course daycare centre was carried out well. It can be seen from how the teacher applies it in daily activities by reading stories, playing games that can stimulate children's language, listening to the radio, dancing, and responding to children. Therefore, research related to the effective implementation of the language development program can be studied further.

Keywords: language development, early childhood, daycare

\footnotetext{
${ }^{1}$ Corresponding Author:

Department of Early Childhood Education

Universitas Negeri Padang, Indonesia

Email: halimatussakdiah1972@gmail.com
} 


\section{INTRODUCTION}

Language is the ability to communicate with other people, including all ways to communicate, where thoughts and feelings are expressed in symbols and symbols to convey an understanding, such as oral, written, collection, painting, and facial expressions (Depdikbud, 1996). Ability shows complex and fantastic human so that that language can develop rapidly from an early age.

Language development starts from a simple environment through direct empirical practice (Veryawan and Jellysha, 2020). Children can acquire language through the surrounding that controls the stimulation of children to speak. It is a manifestation of human behavior (Haryadi and Zamzani, 1996). Language development is also strongly determined by genetic maturity that they believe genetic maturity dramatically determines one's language competence (Purwo, 2015). A new language appears when the child has reached a relatively advanced stage of development, and language experience depends on the set of cognitive development (Ayriza, 2001).

Teaching Indonesian is essentially one way of seeking guidance and development of the Indonesian language in a directed manner. Teaching language to early childhood has a significant meaning and role in forming habits, attitudes, and basic abilities needed by children and helping children develop their language skills (Sarayati, 2019). Language development in children is the detection of symptoms that occur in children in the development process. By knowing the stages of children's language development, teachers can find out the developmental needs of children and stimulate them according to the steps of the child's age (Palupi Yulia, 2018).

Early childhood education is one form of education that focuses on laying the foundation for growth and six developments, namely: moral and religious development, physical development (gross and fine motor coordination), intelligence/cognitive (thinking power, creativity), social-emotional (attitudes and emotions), language and communication, following the uniqueness and stages of development according to the age group that passed by early childhood (Nurjanah and Anggraini, 2020). And daycare is part of early childhood education.

Early childhood is a golden period which is an entire initial period throughout the age range of growth and development of human life (Suryana, 2013). Early childhood education is an effort to stimulate, guide, nurture, and provide learning activities that improve children's knowledge and skills (Abu achmadi dan Cholid Narbuko, 2009). Education and learning for early childhood are education carried out for children aged 0-8 years. Based on differences and children's growth, it is necessary to provide education for early childhood (Eliza, 2013). Education is critical in life to survive. It requires knowledge skills and attitudes so that people can adjust themselves family environment and community circles. Early childhood education greatly influences child growth because it lays the foundation for development (Rahmi, A, \& Mahyuddin, 2019). 
Early childhood education (ECE) is the level of education before primary school education as a coaching effort aimed at children from birth to six years. ECE is carried out through educational feedback to help physical and spiritual growth and development so that children are ready to enter further education (Wibowo, 2012). Therefore, caregivers in daycare play a vital role in the process of child growth and development, especially language development. Delays in language development in children can cause learning disabilities which will make children experience behavioral problems and psychosocial adjustments (Ilya Krisnana, 2016). Teachers as elements of education who always deal directly with children in early childhood education institutions have duties and obligations to develop children's language. Children need support and a positive attitude from the teacher to train children's language skills optimally.

The researcher made the initial observations about children's language development at the Twin Course Daycare in West Pasaman Regency. Some children have speech delays, but daycare has activities that stimulating children to speak and integrate. Based on the existing phenomenon, teachers who work in daycare have long experience in parenting because the daycare center is also an integrated ECE institution, so many parents leave their children in the daycare center. Therefore, researchers are interested in researching how language development activities are applied. This study aims to describe the implementation of language development in children in daycare.

\section{METHOD}

This study uses a qualitative approach. Qualitative research is data collection in a scientific setting using natural methods and carried out by naturally interested people or researchers (Moleong, 2012), while descriptive data is collected in words, pictures, and not numbers (Suharsimi Arikunto, 2006). Qualitative research is used when the problem is not clear to find out hidden meanings, understand social interactions, develop theories, ensure the truth of data, and examine the history of development. This study uses a qualitative descriptive approach that focuses on the effects (impacts) of various factors, giving meaning (meaning) to social phenomena so that this study aims to determine the implementation of language development activities at the Twin Course Pasaman Barat daycare.

In conducting qualitative research, the authors searched for data by observing the daycare and interviewing six caregivers at the child care. Therefore, researchers must have broad theoretical and insightful provisions (Suharsimi Arikunto, 2006) so that they can ask, analyze, and construct the object under study to be more explicit. The initial step in conducting this research was working on initial observations (Puspita, 2019) in twin course daycare. Furthermore, the researchers conducted follow-up observations related to implementing children's language development activities in daycare. In addition, researchers conducted interviews with six caregivers who carried out language-development activities. Other data, the researcher analyzed the existing daycare institution documents related to the evaluation of children's language development. The purpose of this study was to describe the implementation of language development in the twin course daycare in West Pasaman. 


\section{FINDINGS AND DISCUSSION}

The findings in the field regarding the implementation of language development activities at the West Pasaman Twin Course Daycare are as follows:

\section{Observation}

From the results of observations in the field, the researcher found that the implementation of children's language development at the Twin Course Pasaman Barat Daycare included; the teacher makes activities such as placing objects out of the reach of children to train movement and hand-eye coordination. Furthermore, the teacher invites the children to play where the child's nose, eyes, and hands are. Games can be made spontaneously, such as taking turns shaking a rattling toy, gently rubbing the forehead, or clapping (Anita Yus, 2005).

In addition, the teacher reads a book and talks about the children's daily activities. The teacher reads a picture and colour book, invites the child to hold the book, and turns the book's pages. It is well done because when the teacher develops reading, speaking, playing simple games, and encouraging children's efforts (Sukardi, 2008), children will feel happy. The teacher also takes the initiative to make new responses or create new versions of familiar games (Dorothy rich, 2008), showing the names of pictures of objects in the book and mentioning the names of things (Wortham, 2005). It is following the opinion expressed, namely giving and reading stories to children and then asking questions afterward about stories or readings that are read can stimulate and stimulate children to be able to appreciate the story (Eliza, 2017).

In addition, the teacher uses card media in storytelling activities. Using cards in storytelling can train language development in children. (Yulianti, Jaya and Delfi, 2019).

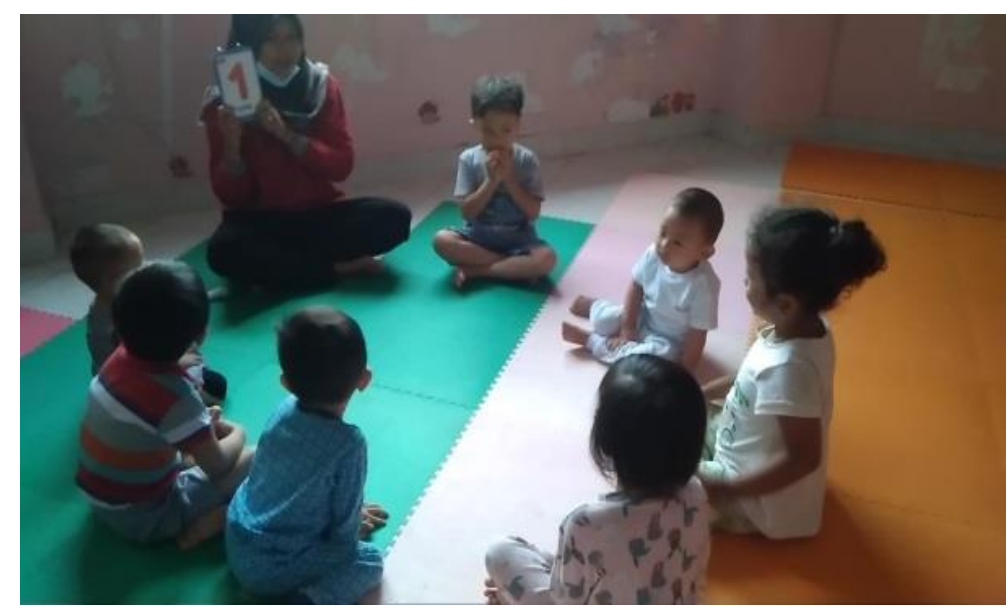

Figure I. Reading using cards

Figure 1 shows a teacher explaining to children how to use cards so that children can understand easily. 


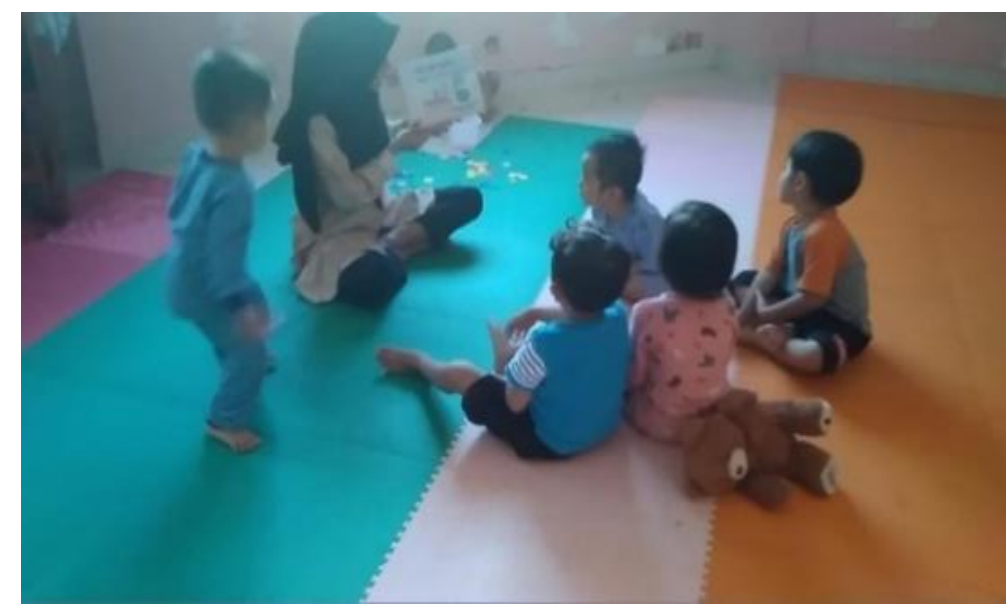

Figure 2. Telling the story from books

Figure 2 describes a teacher telling a story that attracted the children to new knowledge and practice hearing. The implementation of child development activities to be able to speak and understand every word used by children is always carried out every day. With language, children can also express themselves and communicate. They are starting from interacting, learning, and developing (Sri Hastuti, 1999).

\section{Interview}

From the interviews, researchers found that teachers and parents work together in supporting children's language development. Besides teachers, family is also a factor that is considered to have a significant influence in terms of children's readiness to learn and ready to continue their education to a higher level (Syarfina, Yetti and Fridani, 2018). Teachers and parents who tell stories or read books can improve language development in children, enrich vocabulary, teach language structure and learn to pronounce words correctly (Dorothy rich, 2008). If teachers use toys and dolls for storytelling, they will train the child to imagine.

The daycare teacher has an early childhood education background. Teachers provide stimulus to children by teaching children, such as monitoring children's language fluency, listening to children's vocabulary, and seeing language styles and self-expression in speaking.

The obstacles faced by the teacher include when the teacher invites the child to talk in every activity with him, the child does not always respond, even though the child may absorb what the teacher says and does. According to the teachers, even though they often encounter these obstacles, the teacher tries to get the children to respond, for example, by showing more interesting things. For instance, during a shopping role-play activity, the teacher said, "Look, son, this is called spinach. It's green and makes us healthy." Then, the teacher invites the children to sing with gestures and expressions according to the song's lyrics. 


\section{CONCLUSION}

This study describes how children's language development is implemented at the Twin Course West Pasaman Child Care. The activities carried out well can be seen from how the teacher applies them in daily activities, such as reading stories, playing roles, dancing, etc. Another important thing is that daycare centers must be observant and creative in helping children's speaking and respecting skills.

\section{SUGGESTION}

Based on the conclusions obtained in this study, constructive suggestions are proposed for the perfection of qualitative descriptive research in the future. It is suggested for early childhood education stakeholders to improve quality by improving facilities and infrastructure that can support children's activities. Daycare teachers should be able to use fun activities in learning as one of the implementations of toddler language development. For further researchers, it is hoped to reveal more about the development of toddlers' language. Readers are expected to use this research as a source of knowledge or add insight. Further researchers are expected to observe and develop implementations that can be used in language development.

\section{REFERENCE}

Abu achmadi dan Cholid Narbuko (2009) Metodologi Penelitian. Jakarta: PT Bumi Aksara.

Anita Yus (2005) Penilaian Perkembangan Belajar Anak Taman Kanakkanak. Jakarta: Departemen Pendidikan Nasional.

Ayriza, Y. (2001) Menumbuhkan Kesiapan Membaca PadaAnak-Anak Prasekolah melalui Pelatihan Kesadaran Fonologis.

Depdikbud (1996) Metodik Khusus Pengembangan Kemamapuan Berbahasa di Taman KanakKanak. Jakarta: Depdikbud.

Dorothy rich (2008) Sukses untuk Anak-anak Prasekolah. Jakarta: PT. Indeks.

Eliza, D. (2013) 'Penerapan Model Pembelajaran Kontekstual Learning (CTL) Berbasis Centra di Taman Kanak-Kanak.', PEDAGOGI Ilmiah Ilmu Pendidikan, XIII Nomor.

Eliza, D. (2017) ‘Pengembangan Model Pembelajaran Karakter Berbasis Cerita Tradisional Minangkabau Untuk Anak Usia Dini’, Jurnal Anak Usia Dini Dan Pendidikan Anak Usia Dini, Volume 3 N.

Haryadi, H. and Zamzani, Z. (1996) Peningkatan Keterampilan Berbahasa Indonesia. Edited by B. P. P. pendidikan G. S. D. Depdikbud, Dirjend Dikti. Jakarta.

Ilya Krisnana (2016) ‘Peran Asah (3a) Pengasuh Dengan Perkembangan Bahasa Anak Usia 
Toddler Di Taman Penitipan Anak', Ners Vol. 11 No.2 Oktober 2016: 240-245., 11.

Moleong, J. L. (2012) Metodologi Penelitian Kualitatif. Bandung: PT. Remaja Rosdakarya.

Palupi, Y. (2018) Perkembangan Bahasa Pada Anak. Yogyakarta: Proseding Seminar Nasional PGSD UPY.

Purwo, B. (2015) Bahasa dan pendidikan. Jakarta: Pusat Kajian Bahasa dan Budaya, Universitas Katolik Indonesia Atma Jaya.

Puspita, W. (2019) 'Kelekatan Anak dengan Pengasuh Tempat Penitipan Anak', PG-PAUD Trunojoyo : Jurnal Pendidikan dan Pembelajaran Anak Usia Dini, Volume 6,.

Rahmi, A,. \& Mahyuddin, N. (2020). (2019) 'Design \& Application of Storyboard in Teaching Characters for Children Aged 6-8 Years.', pp. 97-100. doi: https://doi.org/10.2991/assehr.k.200715.019.

Sarayati, S. (2019) 'Penggunaan Metode Bercerita Dengan Media Gambar Dalam Upaya Meningkatkan Kemampuan Berbahasa Dan Sikap Mandiri Anak Tk B Dewi Sartika Sintang', DUNIA ANAK: Jurnal Pendidikan Anak Usia Dini, 1(2), pp. 45-55. doi: 10.31932/jpaud.v1i2.387.

Sri Hastuti (1999) Bermain Sambil Belajar. Yogyakarta: Mitra Gama Widya.

Suharsimi Arikunto (2006) Prosedur Penelitian Suatu Pendekatan Praktik. Jakarta: Rineka Cipta.

Sukardi (2008) Penilaian Perkembangan Belajar Anak Taman Kanakkanak. Jakarta: Bumi Aksara.

Suryana, D. (2013) Pendidikan Anak Usia Dini Teori Dan Praktik Pembelajaran). Padang: UNP Prees Padang.

Syarfina, S., Yetti, E. and Fridani, L. (2018) 'PEMAHAMAN GURU PRASEKOLAH RAUDHATUL ATHFAL TENTANG KESIAPAN SEKOLAH ANAK', Jurnal Pendidikan Usia Dini, 12(1), pp. 153-163. doi: 10.21009//JPUD.121.13.

Veryawan and Jellysha (2020) 'Meningkatkan Kemampuan Bahasa Anak Melalui Permainan Kata Orak-Arik', Atfaluna: Journal of Islamic Early Childhood Education, 3(1), pp. 13-22.

Wibowo, agus (2012) Pendidikan Karakter Anak Usia Dini. : Pustaka Belajar. Yogyakarta: Diva Press.

Wortham, S. C. (2005) Assessment in Early Childhood Education. New Jersey: Pearson Education. 
Implementation of language development ... - Halimatus Sakdiah \& Delfi Eliza

Yulianti, E., Jaya, I. and Delfi, E. (2019) 'Pengaruh Role Playing terhadap Pengenalan Literasi Numerasi di Taman Kanak-kanak Twin Course Pasaman Barat. Aulad', Aulad Journal on Early Childhood, 2(2), pp. 41-50. 